\title{
Pengaruh Budaya Organisasi Dan Kepemimpinan Terhadap Kinerja Karyawan Pada Perusahaan One Robotics Education, Tangerang
}

\author{
Putri Nilam Kencana \\ Dosen Fakultas Ekonomi Universitas Pamulang \\ Email:dosen01877@unpam.ac.id
}

\begin{abstract}
ABSTRAK
Tujuan penelitian adalah untuk mengetahui pengaruh budaya organisasi dan kepemimpinan terhadap kinerja karyawan pada Perusahaan One Robotics Education, Tangerang

Metode yang dilakukan dalam penelitian ini adalah metode deskriptif kuantitatif, yaitu melalui pendekatan, pengumpulan data dan analisa menggunakan statistik. Data yang digunakan menggunakan teknik observasi, wawancara, angket (kuesioner sebanyak 53 responden) dan kepustakaan. Metode analisa yang digunakan dalam penelitian ini adalah uji validitas, uji reliabilitas, uji asumsi klasik (uji normalitas, uji heteroskedastisitas, uji multikolinearitas), analisis regresi linier berganda, analisis koefisien korelasi, uji koefisien determinasi dan uji hipotesis (uji T dan Uji F)

Nilai Signifikansi F sebesar 0,000 $(<0,05)$ maka dapat disimpulkan bahwa hipotesis diterima, artinya variabel budaya organisasi dan kepemimpinan berpengaruh signifikan secara bersama-sama terhadap kinerja karyawan. Nilai $R$ (koefisien korelasi) adalah 0,581, maka dapat diartikan derajat hubungan antara variabel budaya organisasi dan kepemimpinan terhadap kinerja karyawan merupakan korelasi sedang. Nilai Koefisien Determinasi (R) tersebut diperoleh sebesar 33,8\%. Hal ini menunjukkan bahwa besarnya variabel budaya organisas dan kepemimpinan dalam upaya meningkatkan kinerja karyawan sebesar 33,8\% sedakan selebihnya sebesar $66,2 \%$ dipengaruhi oleh faktor lain yang tidak diteliti dalam penelitian ini. Uji signifikasi t, nilai signifikasi untuk pengaruh X1 (budaya organisasi) terhadap Y (kinerja karyawan) adalah sebesar $0,000<0,05$ dan nilai $\mathrm{t}$ hitung 2,115>t tabel 2,00856, dapat disimpulkan bahwa Ha1 diterima yang berarti terdapat pengaruh $\mathrm{X} 1$ terhadap $\mathrm{Y}$. nilai signifikasi untuk pengaruh $\mathrm{X} 2$ (kepemimpinan) terhadap Y (Kinejra kayawan) adalah sebesar 0,000 $<0,05$ dan nilai t hitung 2,189 > t tabel 2,00856, dapat disimpulkan bahwa Ha2 diterima yang berarti terdapat pengaruh X2 terhadap Y. Nilai signifikasikan untuk pengaruh X1 (budaya organisasi) terhadap Y (kinerja karyawan) adalah sebesar 0,000 $<0,05$ dan nilai t hitung 2,115 > t tabel 2,00856 dan diketahui nilai signifikasikan untuk pengaruh X2 (kepemimpinan) terhadap Y (kinerja karyawan) adalah sebesar 0,000 $<0,05$ dan nilai t hitung 2,189 > t tabel 2,00856, sehingga dapat disimpulkan Ha1 dan Ha2 diterima yang berarti terdapat pengaruh X1 dan X2 terhadap Y secara bersama-sama. Hal ini berarti budaya organisasi dan kepemimpinan memiliki peran dalam meningkatkan kinerja karyawan pada perusahaan One Robotics Education Tangerang.
\end{abstract}

Kata Kunci: Budaya Organisasi, Kepemimpinan, Kinerja Karyawan 


\section{PENDAHULUAN}

\section{A. Latar Belakang}

Sumber daya manusia merupakan komponen paling penting dalam proses pencapaian tujuan perusahaan, mereka masuk ke dalam organisasi perusahaan sambil membawa karakteristiknya masing-masing.

Dengan

keanekaragaman karakteristik tersebut diharapkan mampu menghasilkan ide-ide yang cemerlang untuk meningkatkan kinerja perusahaan. Keberhasilan sebuah perusahaan sangat bergantung kepada baik dan buruknya kinerja dari perusahaan tersebut. Kinerja dari sebuah perusahaan tergantung kepada kepada kinerja karyawannya dimana setiap karyawan merupakan motor bagi berjalannya sebuah perusahaan. Kinerja yang baik dari karyawan akan berdampak langsung kepada kemajuan atau kemunduran yang diperoleh perusahaan tersebut.

Budaya organisasi yang dianut oleh perusahaan dan diimplementasikan oleh karyawan menjadi perilaku karyawan yang kemudian menentukan arah keberhasilan suatu perusahaan dalam meningkatkan kinerja perusahaan. Budaya organisasi ialah suatu sistem nilai yang merupakan kesepakatan kolektif dari semua yang terlihat dalam perusahaan. Kesepakatan disni adalah dalam hal cara pandang tentang bekerja dan unsurunsurnya. Suatu sistem nilai merupakan konsepsi nilai yang hidup dalam alam pemikiran sekelompok manusia/ individu karyawan dan manajemen. Dalam hal ini Budaya organisasi berkaitan erat dengan persepsi terhadap nilai-nilai dan lingkungannya. Lalu persepsi itu melahirkan makna dan pandangan hidup yang akan mempengaruhi sikap dan tingkah laku karyawan dan manajemen dalam bekerja.

Budaya organisasi dalam organisasi seperti di perusahaan diaktualisasikan sangat beragam. Bisa dalam bentuk dedikasi/loyalitas, tanggung jawab, kerjasama, kedisiplinan, kejujuran, ketekunan, semangat mutu kerja, keadilan, dan integritas kepribadian. Semua bentuk aktualisasi budaya organisasi itu sebenarnya bermakna komitmen. Ada suatu tindakan, dedikasi, dan kesetiaan orang pada janji yang telah dinyatakannya untuk memenuhi tujuan organisasi dan individunya yang telah dipilihnya dalam waktu lama. Hal ini perlu diperhatikan dari karyawan dan manajemen untuk membentuk budaya organisasi yang bertanggung jawab, berdedikasi, dan berintegritas agar kepuasan client dapat mencapai kepuasan yang maksimal. Untuk melihat kondisi awal kineja karyawan pada perusahaan One Robotics Education, Tangerang, maka penulis melakukan pra survey terhadap 53 orang karyawan dengan mengambil sampel dari sebagian populasi dan hasilnya dapat di lihat pada Tabel 1.1 
Tabel 1.1

Penilaian Budaya Organisasi pada Perusahaan One Robotics Education

Tahun 2018

\begin{tabular}{|c|c|c|c|c|}
\hline \multicolumn{4}{|c|}{ UNSUR YANG DINILAI } & \multirow{2}{*}{ Jumlah } \\
\hline \multicolumn{2}{|c|}{ Sasaran Penilaian Budaya Organisasi } & Nilai & Kriteria & \\
\hline \multirow[t]{11}{*}{ Budaya Organisasi } & 1. Inisiatif Individual & 50.00 & Buruk & 50.00 \\
\hline & 2. Toleransi terhadap resiko & 65.00 & Cukup & 65.00 \\
\hline & 3. Arah & 60.00 & Sedang & 65.00 \\
\hline & 4. Integrasi & 55.00 & Sedang & 55.00 \\
\hline & 5. Kontrol & 75.00 & Cukup & 75.00 \\
\hline & 6. Identitas & 60.00 & Sedang & 65.00 \\
\hline & 7. Sistem Imbalan & 50.00 & Buruk & 50.00 \\
\hline & 8. Toleransi terhadap konflik & 60.00 & Sedang & 60.00 \\
\hline & Jumlah & 475.00 & & 485.00 \\
\hline & Nilai Rata-rata & 59.38 & Sedang & \\
\hline & Nilai Budaya Orgnisasi & 59.38 & $60 \%$ & 35.63 \\
\hline \multicolumn{4}{|c|}{ Kriteria: $<=50$ (Buruk), $<=60$ (Sedang), $<=75$ (Cukup), $<=90$ (Baik), $<=99$ (Sangat Baik) } & \\
\hline \multicolumn{4}{|c|}{$\begin{array}{r}\text { Nilai Budaya Organisasi } \\
\end{array}$} & Sedang \\
\hline
\end{tabular}

Dari tabel 1.1 di atas, menunjukkan bahwa penilaian dari unsur budaya organisasi nilai prosentasenya sangat beragam. Inisiatif individual dan sistem imbalan nilainya sangat buruk yaitu hanya 50\%. Untuk arah, integrasi, identitas dan toleransi terhadap konflik nilainya sedang dengan 55\% - 60\% sedangkan toleransi terhadap resiko dan kontrol dengan penilaian cukup. Dari hasil tersebut semua item penilaian tidak ada yang mencapai kategori sangat baik, ini artinya budaya organisasi yang ada harus dievaluasi guna dapat bekerja dengan baik.

Seorang pemimpin harus mampu mempengaruhi para bawahannya untuk bertindak sesuai dengan visi, misi dan tujuan perusahaan. Pemimpin harus mampu memberikan wawasan, membangkitkan kebanggaan, serta menumbuhkan sikap hormat dan kepercayaan dari bawahannya. Pemimpin yang efektif adalah pemimpin yang mengakui kekuatan-kekuatan penting yang terkandung dalam individu. Setiap individu memiliki kebutuhan dan keinginan yang berbeda-beda. Setiap individu memiliki tingkat keahlian yang berbeda-beda pula. Pemimpin harus fleksibel dalam pemahaman segala potensi yang dimiliki oleh individu dan berbagai permasalahan yang dihadapai individu tersebut. Dengan melakukan pendekatan tersebut, pemimpin dapat menerapkan segala peraturan dan kebijakan organisasi serta melimpahkan tugas dan tanggung jawab dengan tepat. Hal ini sejalan dengan usaha untuk menumbuhkan komitmen organisasi dari diri karyawan. Sehingga pemimpin nantinya dapat meningkatkan kepuasan karyawan terhadap pekerjaannya serta dapat meningkatkan kinerja karyawan dengan lebih efektif.

Berikut ini penilaian kepemimpinan yang dilakukan pada tahun 2018 yang ditunjukkan pada tabel 1.2 berikut ini: 
Tabel 1.2

Penilaian Kepemimpinan pada Perusahaan One Robotics Education Tahun 2018

\begin{tabular}{|c|c|c|c|c|}
\hline \multicolumn{4}{|c|}{ UNSUR YANG DINILAI } & \multirow{2}{*}{ Jumlah } \\
\hline \multicolumn{2}{|c|}{ Sasaran Penilaian Kepemimpinan } & Nilai & Kriteria & \\
\hline \multirow[t]{12}{*}{ Kepemimpinan } & 1. Leadership & 55.00 & Sedang & 55.00 \\
\hline & 2. Motivator & 50.00 & Buruk & 50.00 \\
\hline & 3. Integritas & 50.00 & Buruk & 50.00 \\
\hline & 4. Disiplin & 60.00 & Sedang & 60.00 \\
\hline & 5. Koordinasi Kerjasama & 65.00 & Cukup & 65.00 \\
\hline & 6. Supporting & 60.00 & Sedang & 60.00 \\
\hline & 7. Kerjasama & 75.00 & Cukup & 75.00 \\
\hline & 8. Pedelegasian Kewenangan & 65.00 & Cukup & 65.00 \\
\hline & 9. Komunikasi & 60.00 & Sedang & 60.00 \\
\hline & Jumlah & 540.00 & & 540.00 \\
\hline & Nilai Rata-rata & 60.00 & Sedang & \\
\hline & Nilai Kepemimpinan & 60.00 & $60 \%$ & 36.00 \\
\hline \multicolumn{4}{|c|}{ Kriteria: $<=50$ (Buruk), <=60 (Sedang), <=75 (Cukup), <=90 (Baik), <=99 (Sangat Baik) } & \\
\hline \multicolumn{4}{|c|}{ Nilai Kepemimpinan } & Sedang \\
\hline
\end{tabular}

Dari tabel 1.2 di atas, menunjukkan bahwa penilaian dari unsur kepemimpinan nilai prosentasenya sangat beragam. Motivasi dan integritas nilainya sangat buruk yaitu hanya $50 \%$. Untuk leadership, disiplin, supporting, dan komunikasi nilainya sedang dengan 55\%-60\%, sedangkan koordinasi, kerjasama, dan pendelegasian kewenangn dengan penilaian cukup. Dari hasil tersebut semua item penilaian tidak ada yang mencapai kategori sangat baik, ini artinya kepemimpinan yang ada harus di evaluasi guna dapat bekerja dengan baik.

Kepemimpinan pada mencapai jabatan tertentu dan adanya harapan untuk mendapatkan penghargaan hasilnya buruk, sedangkan tantangan pekerjaan dengan nilai cukup serta tanggung jawab pekerjaan dan adanya harapan akan adanya kesejahteraan karyawan hanya pada tingkat penilaian sedang. Tidak adanya pencapaian yang sangat baik mengindikasikan bahwa kepemimpinan di One Robotics Education sangat memerlukan perhatian yang serius bagi manajemen perusahaan. Kondisi ini diperparah dengan tingkat kedisiplinan pegawai yang sering tidak masuk kerja dengan rata-rata tingkat kehadiran pegawai dalam 12 bulan terakhir yang mecapai 8\% selama periode Oktober 2017 sampai September 2018 seperti yang ditunjukkan pada tabel dibawah ini : 
Tabel 1.3

Data Absensi Karyawan One Robotics Education Tahun 2017 - 2018

\begin{tabular}{|l|r|c|c|}
\hline \multirow{2}{*}{ Bulan } & \multirow{2}{*}{ Tahun } & Jumlah pegawai yang absen & \multirow{2}{*}{ Prosentase } \\
\cline { 3 - 3 } & 2017 & 4 & $8 \%$ \\
\hline Oktober & 2017 & 7 & $13 \%$ \\
\hline November & 2017 & 3 & $6 \%$ \\
\hline Desember & 2018 & 6 & $11 \%$ \\
\hline Januari & 2018 & 8 & $15 \%$ \\
\hline Februari & 2018 & 6 & $11 \%$ \\
\hline Maret & 2018 & 5 & $9 \%$ \\
\hline April & 2018 & 3 & $6 \%$ \\
\hline Mei & 2018 & 0 & $0 \%$ \\
\hline Juni & 2018 & 2 & $4 \%$ \\
\hline Juli & 2018 & 4 & $8 \%$ \\
\hline Agustus & 2018 & 4 & $8 \%$ \\
\hline September & & $\mathbf{5}$ & $\mathbf{8 \%}$ \\
\hline Rata-rata per bulan & & & \\
\hline
\end{tabular}

Keterangan: Jumlah karyawan 53 orang

Sumber: Data Absensi Karyawan One Robotics Education 2017 - 2018

Pada tabel 1.3 diatas, menunjukkan angka absensi dari karyawan dinilai dari 1 tahun terakhir pada Oktober 2017 sampai dengan September 2018, secara keseluruhan setiap bulannya karyawan yang tidak masuk kantor dengan tanpa adanya pemberitahuan jumlahnya fluktuatif cenderung meningkat. Kondisi seperti ini jika tidak dilakukan pembenahan jelas akan menurunkan tingkat pelayanan dan dampak lainnya pada kelangsungan hidup perusahaan.

$$
\text { Kinerja karyawan }
$$
merupakan prestasi kerja atau hasil kerja baik kualitas maupun kuantitas yang dicapai oleh seorang karyawan per satuan periode waktu dalam melaksanakan tugas kerjanya sesuai dengan tanggung jawab yang diberikan kepadanya. Setiap organisasi atau instansi dalam melaksanakan program yang diarahkan selalu berdaya guna untuk mencapai tujuan perusahaan. Salah satu crania adalah meningkatkan kinerja karyawan

Perusahaan One Robotics Education merupakan perusahaan yang bergerak dibidang edukasi. Perusahaan tersebut merupakan perusahaan yang berdiri tahun 2011. Penelitian ini memfokuskan pada karyawan One Robotics Education yang berlokasi di Ciledug-Tangerang karena disini pusat kegiatan manajerial dilakukan. Perusahaan ini bergerak dibidang edukasi sebagaimana telah dijelaskan di atas yang mengajarkan tentang edukasi robotika yang diselenggarakan di setiap sekolah yang berbeda-beda Nasional maupun International SchoolseJABODETABEK.Sampa i saat ini perusahaan One Robotics Education memiliki peserta didik sebanyak kurang lebih 2000 siswa/ 
I yang tersebar di JABODETABEK. Budaya organisasi pada perusahaan One Robotics Education yang kurang optimal diduga muncul karena lingkungan kerja yang kurang adanya komunikasi secara terbuka antara pimpinan dan karyawan, mengenai perbedaan karakter individu para karyawan sendiri, lingkungan kerja yang kondusif serta perhatian bagi karakteristik individu sendiri dinilai sangatlah penting untuk menungjang kinerja karyawan lebih optimal bagi peningkatan produktifitas perusahaan. Dan kinerja dalam perusahaan One Robotics Education terjadinya penurunan salah satunya dari segi kualitas kerja, ketepatan waktu, dan komunikasi terbuka. Berikut ini hasil evaluasi penilaian kinerja pegawai secara rata-rata di Perusahaan One Robotics Educatiion periode 2015-2018 yang ditampilkan pada grafik dibawah ini :

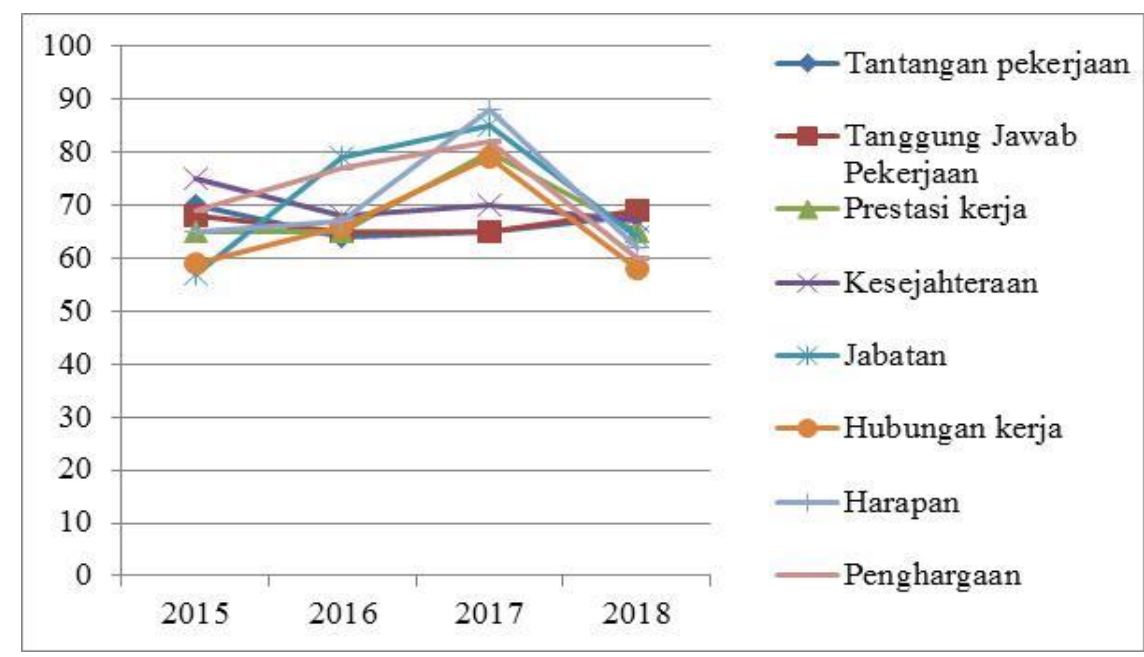

Data diolah 2018

Gambar 1.1

Grafik Perkembangan Prosentase Penilaian Kinerja

Pada gambar grafik diatas, menunjukkan bahwa secara keseluruhan nilai pencapaian secara kolektif kinerja pada Perusahaan One Robotics Education dari tahun 2015 sampai dengan tahun 2018 baik itu pada tantangan pekerjaan, tanggung jawab individu, prestasi kerja, kesejahteraah karyawan, jenjang karir, hubungan kerja antara karyawan dan pimpinan perusahaan, harapan karyawan pada perusahaan, dan penghargaan yang diberikan perusahaan pada karywan menunjukkan persentase pencapaian yang besaran persentasenya berfluktuatif cenderung naik dari 2015 sampai 2017, namun menurun pada tahun 2018. Hal ini menjadi tantangan tersendiri untuk perusahaan agar pencapaian yang dilakukan harus memiliki komitmen dalam kinerja karyawan itu sendiri.

Berdasarkan uraian di atas, maka penulis tertarik untuk melakukan penelitian dengan judul 
"Pengaruh Budaya Organisasi dan Gaya Kepemimpinan Terhadap Kinerja Karyawan pada Perusahaan One Robotics Education Ciledug-Tangerang".

\section{B. Hipotesis}

Hipotesis adalah jawaban sementara terhadap masalah penelitian yang harus diuji secara empiris, Suryabrata (2011:23). Hipotesis dari penelitian ini dapat diartikan suatu kesimpulan yang sifatnya sementara untuk menjawab permasalahan yang akan diajukan sampai terbukti melalui data yang terkumpul.

Dalam penelitian ini terdapat hipotesis sebagai berikut:

Ha1: Terdapat pengaruh antara budaya organisasi terhadap kinerja karyawan perusahaan One Robotics Education.

Ha2: Terdapat pengaruh antara kepemimpinan terhadap kinerja karyawan perusahaan One Robotics Education.

Ha3: Tidak ada pengaruh antara budaya organisasi dan kepemimpinan terhadap kinerja karyawan perusahaan One Robotics Education.

\section{HASIL PENELITIAN DAN PEMBAHASAN}

A. Hasil Penelitian

1. Uji Validitas

a. Uji Validitas Variabel (X1)

Tabel 4.1

Hasil Pengujian Perhitungan

Validitas Variabel X2

\begin{tabular}{|c|c|c|c|}
\hline Item & $\mathbf{r}_{\text {hitung }}$ & $\mathbf{R}_{\text {tabel }}$ & Keputusan \\
\hline 1 & 0.320 & 0.271 & Valid \\
\hline 2 & 0.574 & 0.271 & Valid \\
\hline 3 & 0.550 & 0.271 & Valid \\
\hline 4 & 0.645 & 0.271 & Valid \\
\hline 5 & 0.563 & 0.271 & Valid \\
\hline 6 & 0.479 & 0.271 & Valid \\
\hline 7 & 0.379 & 0.271 & Valid \\
\hline 8 & 0.514 & 0.271 & \\
\hline
\end{tabular}

Sumber : Output SPSS versi 2018

Berdasarkan hasil uji validitas diatas, peneliti memiliki hasil jawaban kuisioner dari responden untuk pengaruh budaya organisasi terhadap kinerja karyawan yaitu pada tabel 4.6 sebagai berikut:

Tabel 4.2 Hasil Jawaban Responden Budaya Organisasi (X1)

\begin{tabular}{|c|c|c|c|c|c|c|c|}
\hline No & Pertanyaan & SS & $\mathrm{S}$ & $\mathrm{KS}$ & TS & STS & Jumlah \\
\hline \multirow{2}{*}{1} & \multirow{2}{*}{$\begin{array}{l}\text { Bagaimana jika anda melanggar peraturan (keterlambatan } \\
\text { jam kerja) akan diberikan sanksi berupa potongan gaji }\end{array}$} & 1 & 22 & 28 & 2 & o & 53 \\
\hline & & $2 \%$ & $42 \%$ & $53 \%$ & $4 \%$ & $0 \%$ & $100 \%$ \\
\hline \multirow{2}{*}{2} & \multirow{2}{*}{$\begin{array}{l}\text { Bagaimana jika masa kontrak kerja karyawan diputuskan } \\
\text { secara sepihak oleh perusahaan karena alasan menurunnya } \\
\text { produktivitas anda }\end{array}$} & 7 & 19 & 26 & 1 & 0 & 53 \\
\hline & & $13 \%$ & $36 \%$ & $49 \%$ & $2 \%$ & $0 \%$ & $100 \%$ \\
\hline \multirow{2}{*}{3} & \multirow{2}{*}{$\begin{array}{l}\text { Perusahaan berhak memberikan insentif terhadap karyawan } \\
\text { yang melebihi jam kerja }\end{array}$} & 13 & 29 & 10 & 1 & 0 & 53 \\
\hline & & $25 \%$ & $55 \%$ & $19 \%$ & $2 \%$ & $0 \%$ & $100 \%$ \\
\hline \multirow{2}{*}{4} & \multirow{2}{*}{$\begin{array}{l}\text { Perusahaan berhak memberikan teguran jika komunikasi } \\
\text { dalam pekerjaan tidak efektif }\end{array}$} & 9 & 30 & 11 & 3 & 0 & 53 \\
\hline & & $17 \%$ & $57 \%$ & $21 \%$ & $6 \%$ & $0 \%$ & $100 \%$ \\
\hline \multirow[b]{2}{*}{5} & \multirow{2}{*}{$\begin{array}{l}\text { Hubungan yang baik antara pimpinan dan bawahan dapat } \\
\text { menciptakan suasana kerja yang kondusif }\end{array}$} & 9 & 25 & 16 & 2 & 1 & 53 \\
\hline & & $17 \%$ & $47 \%$ & $30 \%$ & $4 \%$ & $2 \%$ & $100 \%$ \\
\hline \multirow{2}{*}{6} & \multirow{2}{*}{$\begin{array}{l}\text { Dukungan kerjasama antara atasan dan bawahan dengan } \\
\text { dasar saling membutuhkan }\end{array}$} & 6 & 32 & 14 & 1 & 0 & 53 \\
\hline & & $11 \%$ & $60 \%$ & $26 \%$ & $2 \%$ & $0 \%$ & $100 \%$ \\
\hline \multirow{2}{*}{7} & \multirow{2}{*}{$\begin{array}{l}\text { Karyawan yang disiplin akan mencerminkan hubungan } \\
\text { keharmonisan antara karyawan dengan manajemen serta } \\
\text { pelanggan (ruang lingkupnya) }\end{array}$} & 13 & 23 & 16 & 0 & 1 & 53 \\
\hline & & $25 \%$ & $43 \%$ & $30 \%$ & $0 \%$ & $2 \%$ & $100 \%$ \\
\hline \multirow{2}{*}{8} & \multirow{2}{*}{$\begin{array}{l}\text { Kepercayaan pelanggan terhadap perusahaan tercermin dari } \\
\text { sikap loyalitas perusahaan. }\end{array}$} & 13 & 22 & 13 & 5 & 0 & 53 \\
\hline & & $25 \%$ & $42 \%$ & $25 \%$ & $9 \%$ & $0 \%$ & $100 \%$ \\
\hline & Jumlah & 71 & 202 & 134 & 15 & 2 & 424 \\
\hline & Persentase & $17 \%$ & $48 \%$ & $32 \%$ & $4 \%$ & $0.5 \%$ & $100 \%$ \\
\hline
\end{tabular}

Data diolah (2018) 
Berdasarkan tabel diatas, diketahui bahwa ratarata responden menyatakan setuju, hal ini terlihat dari jawaban responden yang menyatakan setuju dan sangat setuju sebesar $(47,6 \%+16,7 \%)=64,4 \%$. Hal ini menujukkan bahwa, pendapat responden mengenai budaya organisasi sudah baik. Untuk lebih baik lagi pemimpin dan perusahaan perlu membangun budaya organisasi dengan lebih berkomitmen, kerjasama dan sepakat pada tujuan atau visi dan misi perusahaan. b. Uji Validitas Variabel (X2)

Tabel 4.3

Hasil Pengujian Perhitungan Validitas Variabel X2

\begin{tabular}{|c|c|c|c|}
\hline Item & $\mathbf{r}_{\text {hitung }}$ & $\mathbf{R}_{\text {tabel }}$ & Keputusan \\
\hline 1 & 0.345 & 0.271 & Valid \\
\hline 2 & 0.448 & 0.271 & Valid \\
\hline 3 & 0.461 & 0.271 & Valid \\
\hline 4 & 0.392 & 0.271 & Valid \\
\hline 5 & 0.396 & 0.271 & Valid \\
\hline 6 & 0.549 & 0.271 & Valid \\
\hline 7 & 0.627 & 0.271 & Valid \\
\hline 8 & 0.658 & 0.271 & Valid \\
\hline
\end{tabular}

Sumber : Output SPSS versi 2018

Berdasarkan hasil uji validitas diatas, peneliti memiliki hasil jawaban kuisioner dari responden untuk pengaruh kepemimpinan terhadap kinerja karyawan yaitu pada tabel 4.8 sebagai berikut:

Tabel 4.4

Hasil Jawaban Responden Kepemimpinan (X2)

\begin{tabular}{|c|c|c|c|c|c|c|c|}
\hline No & Pertanyaan & $\mathrm{SS}$ & $\mathrm{S}$ & $\mathrm{KS}$ & TS & STS & Jumlah \\
\hline \multirow{2}{*}{1} & \multirow{2}{*}{$\begin{array}{l}\text { Pemimpin memiliki rasa rendah hati, menghormati bawahan } \\
\text { sebagai rekan kerja }\end{array}$} & 16 & 22 & 15 & 0 & 0 & 53 \\
\hline & & $30 \%$ & $42 \%$ & $28 \%$ & $0 \%$ & $0 \%$ & $100 \%$ \\
\hline \multirow{2}{*}{2} & \multirow{2}{*}{$\begin{array}{l}\text { Pimpinan menaruh kepercayaan yang tinggi kepada bawahan } \\
\text { bagaimana pekerjaan harus diselesaikan }\end{array}$} & 9 & 29 & 12 & 3 & 0 & 53 \\
\hline & & $17 \%$ & $55 \%$ & $23 \%$ & $6 \%$ & $0 \%$ & $100 \%$ \\
\hline \multirow{2}{*}{3} & \multirow{2}{*}{$\begin{array}{l}\text { Pimpinan bersikap tegas dan selalu mendorong bawahan } \\
\text { untuk bersama-sama melakukan upaya maksimal mencapai } \\
\text { tujuan perusahaan }\end{array}$} & 7 & 25 & 14 & 7 & 0 & 53 \\
\hline & & $13 \%$ & $47 \%$ & $26 \%$ & $13 \%$ & $0 \%$ & $100 \%$ \\
\hline \multirow{2}{*}{4} & \multirow{2}{*}{$\begin{array}{l}\text { Pimpinan mampu mendeskripsikan secara jelas arah dan } \\
\text { tujuan dari pekerjaan kepada pegawai }\end{array}$} & 5 & 27 & 16 & 5 & 0 & 53 \\
\hline & & $9 \%$ & $51 \%$ & $30 \%$ & $9 \%$ & $0 \%$ & $100 \%$ \\
\hline \multirow{2}{*}{5} & \multirow{2}{*}{$\begin{array}{l}\text { Pimpinan menyampaikan ide-ide atau gagasan yang kreatif } \\
\text { yang sangat membantu dalam penyelesaian pekerjaan }\end{array}$} & 6 & 28 & 16 & 3 & 0 & 53 \\
\hline & & $11 \%$ & $53 \%$ & $30 \%$ & $6 \%$ & $0 \%$ & $100 \%$ \\
\hline \multirow{2}{*}{6} & \multirow{2}{*}{$\begin{array}{l}\text { Permasalahan yang timbul dalam pekerjaan dapat } \\
\text { diselesaikan dengan bijaksana dan pendekatan yang baik }\end{array}$} & 11 & 17 & 22 & 3 & 0 & 53 \\
\hline & & $21 \%$ & $32 \%$ & $42 \%$ & $6 \%$ & $0 \%$ & $100 \%$ \\
\hline \multirow{2}{*}{7} & \multirow{2}{*}{$\begin{array}{l}\text { Pimpinan mengadakan program-program baru untuk } \\
\text { pengembangan karir pegawai }\end{array}$} & 4 & 22 & 23 & 4 & 0 & 53 \\
\hline & & $8 \%$ & $42 \%$ & $43 \%$ & $8 \%$ & $0 \%$ & $100 \%$ \\
\hline \multirow{2}{*}{8} & \multirow{2}{*}{$\begin{array}{l}\text { Suasana kerja yang baik selama ini berhasil dilakukan oleh } \\
\text { pimpinan }\end{array}$} & 22 & 19 & 9 & 3 & 0 & 53 \\
\hline & & $42 \%$ & $36 \%$ & $17 \%$ & $6 \%$ & $0 \%$ & $100 \%$ \\
\hline & Jumlah & 80 & 189 & 127 & 28 & 0 & 424 \\
\hline & Persentase & $19 \%$ & $45 \%$ & $30 \%$ & $7 \%$ & $0.0 \%$ & $100 \%$ \\
\hline
\end{tabular}

\section{Data diolah (2018)}

Berdasarkan tabel diatas, diketahui bahwa ratarata responden menyatakan setuju, hal ini terlihat dari jawaban responden yang menyatakan setuju dan sangat setuju sebesar $(44,6 \%+18,9 \%)=63,4 \%$.

pendapat responden mengenai kepemimpinan sudah baik. Untuk lebih baik lagi pemimpin perlu menciptakan suasana kerja yang lebih baik didalam maupun diluar kantor.

Hal ini menujukkan bahwa, 


\section{c. Uji Validitas Variabel (Y)}

Tabel 4.5

Hasil Pengujian Perhitungan Validitas Variabel X2

\begin{tabular}{|c|c|c|c|}
\hline Item & rhitung $_{\text {rem }}$ & $\mathbf{R}_{\text {tabel }}$ & Keputusan \\
\hline 1 & 0.697 & 0.271 & Valid \\
\hline 2 & 0.806 & 0.271 & Valid \\
\hline 3 & 0.715 & 0.271 & Valid \\
\hline 4 & 0.557 & 0.271 & Valid \\
\hline 5 & 0.578 & 0.271 & Valid \\
\hline 6 & 0.810 & 0.271 & Valid \\
\hline 7 & 0.403 & 0.271 & Valid \\
\hline 8 & 0.397 & 0.271 & \\
\hline
\end{tabular}

Sumber : output SPSS (2018)

Berdasarkan hasil uji validitas diatas, peneliti memiliki hasil jawaban kuisioner dari responden

untuk

pengaruh kepemimpinan terhadap kinerja karyawan yaitu pada tabel 4.10 sebagai berikut:

Tabel 4.6

Hasil Jawaban Responden Kinerja Karyawan (Y)

\begin{tabular}{|c|c|c|c|c|c|c|c|}
\hline No & Pertanyaan & SS & $\frac{2}{d}$ & KS & TS & STS & Jumlah \\
\hline \multirow{2}{*}{1} & \multirow{2}{*}{$\begin{array}{l}\text { Pekerjaan yang saya lakukan penuh tantangan dan } \\
\text { mendapatkan support dari sesama karyawan lainnya }\end{array}$} & 16 & 28 & 8 & 1 & 0 & 53 \\
\hline & & $30 \%$ & $53 \%$ & $15 \%$ & $2 \%$ & $0 \%$ & $100 \%$ \\
\hline \multirow{2}{*}{2} & \multirow{2}{*}{ waktu untuk menyelesaikan pekerjaan saya sudah cukup } & 15 & 24 & 11 & 3 & 0 & 53 \\
\hline & & $28 \%$ & $45 \%$ & $21 \%$ & $6 \%$ & $0 \%$ & $100 \%$ \\
\hline \multirow{2}{*}{3} & \multirow{2}{*}{$\begin{array}{l}\text { Saya senantiasa menyesaikan pekerjaan dengan ketelitian } \\
\text { dan dapat meminimalisir jumlah kesalahan yang dalam } \\
\text { melaksanakan pekerjaan }\end{array}$} & 17 & 23 & 9 & 4 & 0 & 53 \\
\hline & & $32 \%$ & $43 \%$ & $17 \%$ & $8 \%$ & $0 \%$ & $100 \%$ \\
\hline \multirow{2}{*}{4} & \multirow{2}{*}{$\begin{array}{l}\text { Dalam hal pekerjaan tertentu, saya selesaikan bersama-sama } \\
\text { dengan rekan kerja menurut waktu dan bidang tugas yang } \\
\text { ditentukan }\end{array}$} & 9 & 19 & 22 & 3 & 0 & 53 \\
\hline & & $17 \%$ & $36 \%$ & $42 \%$ & $6 \%$ & $0 \%$ & $100 \%$ \\
\hline \multirow{2}{*}{5} & \multirow{2}{*}{$\begin{array}{l}\text { Dalam menjalankan pekerjaan keakuratan dan kualitas } \\
\text { pekerjaan menjadi acuan saya }\end{array}$} & 16 & 25 & 11 & 1 & 0 & 53 \\
\hline & & $30 \%$ & $47 \%$ & $21 \%$ & $2 \%$ & $0 \%$ & $100 \%$ \\
\hline \multirow{2}{*}{6} & \multirow{2}{*}{$\begin{array}{l}\text { Pekerjaan saya lakukan dengan jadwal dan waktu yang telah } \\
\text { ditentukan }\end{array}$} & 15 & 24 & 10 & 4 & 0 & 53 \\
\hline & & $28 \%$ & $45 \%$ & $19 \%$ & $8 \%$ & $0 \%$ & $100 \%$ \\
\hline \multirow{2}{*}{7} & \multirow{2}{*}{$\begin{array}{l}\text { Kemampuan yang saya miliki dan dibantu dengan peralatan } \\
\text { yang cukup bekerja membantu dalam saya bekerja secara } \\
\text { optimal }\end{array}$} & 7 & 28 & 16 & 2 & 0 & 53 \\
\hline & & $13 \%$ & $53 \%$ & $30 \%$ & $4 \%$ & $0 \%$ & $100 \%$ \\
\hline \multirow{2}{*}{8} & \multirow{2}{*}{$\begin{array}{l}\text { Saya merasa cukup memiliki kemampuan dalam } \\
\text { mengevaluasi kesalahan yang saya lakukan }\end{array}$} & 14 & 23 & 13 & 3 & 0 & 53 \\
\hline & & $26 \%$ & $43 \%$ & $25 \%$ & $6 \%$ & $0 \%$ & $100 \%$ \\
\hline & Jumlah & 109 & 194 & 100 & 21 & 0 & 424 \\
\hline & Persentase & $26 \%$ & $46 \%$ & $24 \%$ & $5 \%$ & $0.0 \%$ & $100 \%$ \\
\hline
\end{tabular}

\section{Data diolah (2018)}

Berdasarkan tabel diatas diketahui bahwa ratarata responden menyatakan setuju, hal ini terlihat dari jawaban responden yang menyatakan setuju dan sangat setuju sebesar $(45,8 \%+25,7 \%)=71,5 \%$. Hal ini menunjukkan bahwa pendapat responden mengenai kinerja karyawan

sudah baik. Untuk lebih baik lagi perlu pemberian waktu penyelesaian pekerjaan yang jelas serta mengukur kemampuan kerja karyawan.

\section{Uji Reliabilitas}

\section{a. Uji Reliabilitas Variabel X1 \\ Setelah semua} pernyataan dinyatakan valid maka uji selanjutnya adalah 
uji reliabilitas kuesioner. Kemudian penulis menganalisa dengan rumus alpha cronbach dengan program SPSS versi 20.

$\mathrm{r}_{\text {cronbach }}$ variabel $\mathrm{X} 1$ dapat dilihat bernilai 0,578 , sedangkan $\mathrm{r}_{\text {tabel }}$ adalah 0,271.Dengan demikian jika $r_{\text {alpha }}$ positif dan lebih besar dari $r_{\text {tabel }}$ maka butiir kuesioner indikatrp variabel $\mathrm{X} 1$ dinyatakan reliabel atau benar sesuai dengan indikator yang telah di tetapkan.

b. Uji Reliabilitas Variabel X2

Setelah semua pernyataan dinyatakan valid maka uji selanjutnya adalah uji reliabilitas kuesioner. Kemudian penulis menganalisa dengan rumus alpha cronbach dengan program SPSS versi 20.

$r_{\text {cronbachVariabel }} \mathrm{X} 2$ dapat dilihat bernilai 0,540 , sedangkan $r_{\text {tabel }}$ adalah 0,271.Dengan demikian jika $r_{\text {alpha }}$ positif dan lebih besar dari $r_{\text {tabel }}$ maka butir kuesioner indikator variabel X2 dinyatakan reliabel atau benar sesuai dengan indikator yang telah ditetapkan.

c. Uji Reliabilitas Variabel Y Setelah semua pernyataan dinyatakan valid maka uji selanjutnya adalah uji reliabilitas kuesioner. Kemudian penulis menganalisa dengan rumus alpha cronbach dengan program SPSS versi 20. $r_{\text {cronbachVariabel }} \quad \mathrm{Y}$ dapat dilihat bernilai 0,775 , sedangkan $r_{\text {tabel }}$ adalah 0,334 . Dengan demikian jika $r_{\text {alpha }}$ positif dan lebih besar dari $r_{\text {tabel }}$ maka butir kuesioner indikator variabel $\mathrm{Y}$ dinyatakan reliabel atau benar sesuai dengan indikator yang telah ditetapkan.

Tabel 4.7

Hasil Pengujian perhitungan

Reliabilitas variabel X1, X2 dan Variabel Y

\begin{tabular}{|c|c|c|c|c|}
\hline Item & Variabel & $\mathrm{r}_{\text {cronbach }}$ & $\mathrm{r}_{\text {tab }}$ & Keputusan \\
\hline 1 & Budaya Organisasi (X1) & 0.578 & 0,271 & Reliabel \\
\hline 2 & Kepemimpinan (X2) & 0.540 & 0,271 & Reliabel \\
\hline 3 & Kinerja Karyawan (Y) & 0.775 & 0,271 & Reliabel \\
\hline
\end{tabular}

Sumber : output SPSS (2018)

3. Uji Asumsi Klasik

a. Uji Normalitas

Tabel 4.8

Hasil Perhitungan Uji

Normalitas

One-Sample Kolmogorov-Smirnov Test

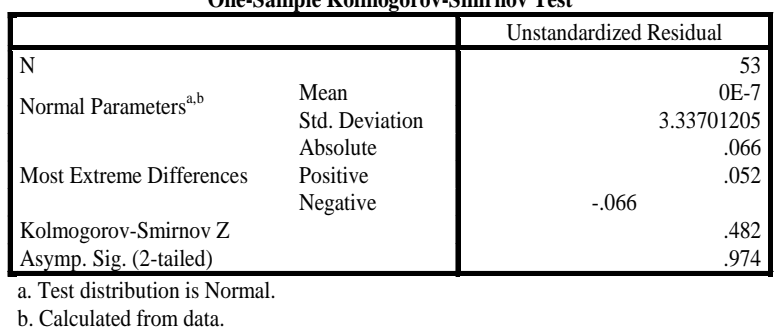

b. Calculated from data.

Sumber:Data menggunakan SPSS versi 20.00

Berdasarkan output di atas diketahui, bahwa nilai signifikansi sebesar 0,974 lebih besar dari 0,005 sehingga dapat disimpulkan bahwa data yang kita kaji berdistribusi normal. 
b. Uji Heteroskedastisitas

Hasil Uji Heteroskedastisitas

Dengan Grafik ScatterPlot Gambar 4.1

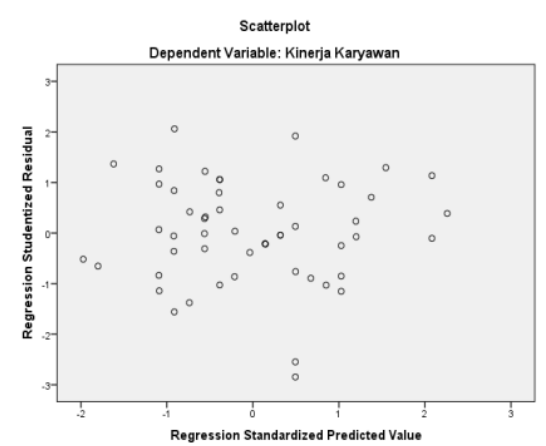

Sumber : Data diolah menggunakan SPSS versi 20.00

Pada gambar 4.2 diatas terlihat bahwa titik-titik menyebar secara acak dibawah dan diatas angka nol, sehingga dapat disimpulkan tidak terjadi Heteroskedastisitas.

\section{c. Uji Multikolinearitas}

Tabel 4.9

Hasil Uji Multikolinearitas Dengan Kinerja Karyawan Sebagai Variabel Dependen Coefficients $^{\mathrm{a}}$

\begin{tabular}{|ll|r|r|}
\hline \multirow{2}{*}{ Model } & \multicolumn{2}{|c|}{ Collinearity Statistics } \\
\cline { 3 - 4 } & & Tolerance & VIF \\
\hline \multirow{2}{*}{1} & (Constant) & & \\
& Budaya Organisasi & .595 & 1.682 \\
& Kepemimpinan & .595 & 1.682 \\
\hline
\end{tabular}

a. Dependent Variable: Kinerja Karyawan

Sumber : Data diolah menggunakan SPSS versi 2018

Pada tabel diatas, memperlihatkan bahwa nilai Variance Inflation Factor (VIF) untuk variabel Budaya Organisasi $\left(\mathrm{X}_{1}\right)$ diperoleh sebesar 1,682 dan Kepemimpinan $\left(\mathrm{X}_{2}\right)$ diperoleh sebesar 1,682 dimana masing- masing nilai tolerance variabel bebas kurang dari 1 dan nilai VIF kurang dari 10 , dengan demikian model regresi ini tidak terjadi korelasi antar variabel independen didalam persamaan itu sendiri atau tidak ada multikolinearitas.

\section{B. Metode Analisis Data}

\section{Analisis Regresi Linier Berganda}

Tabel 4.10

Hasil Pengolahan Regresi

Berganda Variabel Budaya Organisasi $\left(\mathrm{X}_{1}\right)$ dan

Kepemimpinan $\left(\mathbf{X}_{2}\right)$

\begin{tabular}{|l|r|r|r|r|r|}
\hline Model & \multicolumn{3}{|l|}{ Unstandardized Coefficients } & $\begin{array}{c}\text { Standardized } \\
\text { Coefficients }\end{array}$ & \multicolumn{1}{c|}{ Sig. } \\
\cline { 2 - 4 } & \multicolumn{1}{|c|}{ B } & Std. Error & \multicolumn{1}{c|}{ Beta } & & \\
\hline (Constant) & 6.097 & 5.030 & & 1.212 & .231 \\
1 Budaya Organisasi & .417 & .197 & .316 & 2.115 & .039 \\
Kepemimpinan & .423 & .193 & .327 & 2.189 & .033 \\
\hline
\end{tabular}

Sumber : Data diolah menggunakan SPSS versi 2018

Berdasarkan hasil

perhitungan regresi pada tabel diatas, diperoleh persamaan regresinya $Y=6,097+0,417 X_{1}$ $+0,423 \mathrm{X}_{2}$

\section{Analisis Koefisien Korelasi}

Tabel 4.11

Hasil Analisis Korelasi Model Summary ${ }^{b}$

\begin{tabular}{|l|c|r|r|r|r|r|r|r|r|}
\hline Model & $\mathrm{R}$ & $\mathrm{R}$ & Adjust \\
Square & $\begin{array}{c}\text { Std. } \mathrm{R} \\
\text { Squar } \\
\mathrm{e}\end{array}$ & $\begin{array}{c}\text { Error of } \\
\text { the } \\
\text { Estimat } \\
\mathrm{e}\end{array}$ & $\begin{array}{c}\text { R Square } \\
\text { Change }\end{array}$ & $\begin{array}{c}\mathrm{F} \\
\text { Change }\end{array}$ & $\mathrm{df1}$ & $\mathrm{df2}$ & $\begin{array}{c}\text { Sig. F } \\
\text { Change }\end{array}$ \\
\hline 1 & $.581^{\mathrm{a}}$ & .338 & .311 & $\begin{array}{r}3.4031 \\
0\end{array}$ & .338 & 12.754 & 2 & 50 & .000 \\
\hline
\end{tabular}

a. Predictors: (Constant), Kepemimpinan, Budaya Organisasi

b. Dependent Variable: Kinerja Karyawan

Sumber : Data diolah menggunakan SPSS 
Nilai R (Koefisien Korelasi) adalah 0,581. Maka dapat di artikan drajat hubungan antara variabel budaya organisasi dan variabel kepemimpinan terhadap kinerja karyawan merupakan korelasi sedang.

\section{Uji Koefisien Determinasi} $\left(\mathbf{R}^{2}\right)$

Tabel 4.12

Uji Koefisien Determinasi Model Summary ${ }^{\mathrm{b}}$

\begin{tabular}{|l|r|r|r|r|}
\hline Model & \multicolumn{1}{|c|}{ R } & R Square & \multicolumn{1}{|c|}{$\begin{array}{c}\text { Adjusted R } \\
\text { Square }\end{array}$} & \multicolumn{1}{|c|}{$\begin{array}{c}\text { Std. Error of the } \\
\text { Estimate }\end{array}$} \\
\hline 1 & $.581^{\mathrm{a}}$ & .338 & .311 & 3.40310 \\
\hline
\end{tabular}

a. Predictors: (Constant), Kepemimpinan, Budaya Organisasi b. Dependent Variable: Kinerija Karyawan

Sumber : Data diolah menggunakan SPSS versi 2018

Dari tabel diatas dapat dilihat bahwa Rsquare sebesar 0,338 atau 33,8\%. Hal ini menunjukkan bahwa budaya organisasi dan kepemimpinan memberikan konstribusi terhadap kinerja karyawan sebesar $33,8 \%$ dan sisanya $66,2 \%$ dikontribusi oleh variabel lain diluar penelitian

\section{Pengujian Hipotesis}

\section{Uji Hipotesis secara parsial ( $t$ hitung)}

Tabel 4.13

Hasil Uji t

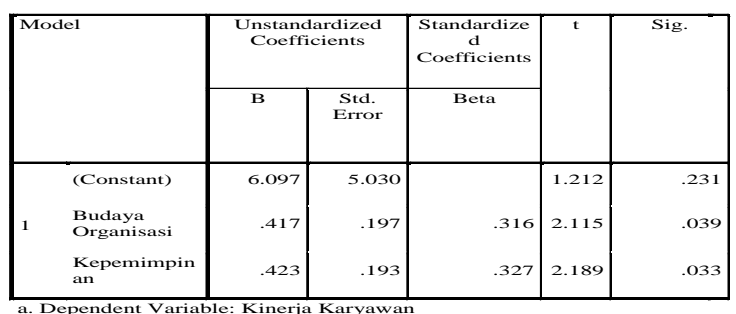

Sumber : Data diolah menggunakan SPSS versi 2018

Berdasarkan data diatas, maka dapat simpulkan sebagai berikut :

1) Pengaruh Budaya Organisasi Terhadap Kinerja Karyawan Berdasarkan $\quad 4.17$ diatas dapat diketahui variabel budaya organisasi memiliki nilai t hitung 2,115 $>\mathrm{t}$ tabel 2,00856 dengan nilai signifikan $0,000<0,05$. Hal ini menunjukkan bahwa Ho ditolak dan Ha1 diterima artinya budaya organisasi berpengaruh positif secara signifikan terhadap kinerja karyawan. Artinya budaya organisasi secara parsial berpengaruh terhadap kinerja karyawan. Sehingga, jika nilai budaya organisasi naik maka kinerja karyawan akan meningkat.

2) Pengaruh Kepemimpinan Terhadap Kinerja Karyawan Berdasarkan $\quad 4.17$ diatas dapat diketahui variabel kepemimpinan memiliki nilai t hitung 2,189 $>\mathrm{t}$ tabel 2,00856 dengan nilai signifikan $0,000<0,05$. Hal ini menunjukkan bahwa Ho ditolak dan Ha2 diterima artinya kepemimpinan berpengaruh positif secara signifikan terhadap kinerja karyawan. Artinya kepemimpinan secara parsial berpengaruh terhadap kinerja karyawan. Sehingga, jika nilai kepemimpinan naik maka kinerja karyawan akan meningkat. 
Hal ini berarti budaya organisasi dan kepemimpinan cukup memiliki peranan dalam meningkatkan kinerja karyawan pada perusahaan One Robotics Education.

2. Uji Hipotesis Secara Simultan (Uji F)

Tabel 4.14

Hasil Uji F

\begin{tabular}{|c|c|c|c|c|c|}
\hline Model & $\begin{array}{l}\text { Sum of } \\
\text { Squares }\end{array}$ & Df & $\begin{array}{c}\text { Mean } \\
\text { Square }\end{array}$ & $\mathrm{F}$ & Sig. \\
\hline $\begin{array}{l}\text { Regressi } \\
\text { on } \\
\text { Residual } \\
\text { Total }\end{array}$ & $\begin{array}{l}295.399 \\
579.054 \\
874.453\end{array}$ & $\begin{array}{r}2 \\
50 \\
52\end{array}$ & $\begin{array}{r}147.700 \\
11.581\end{array}$ & 12.754 & $.000^{\mathrm{b}}$ \\
\hline
\end{tabular}

b. Predictors: (Constant), Kepemimpinan, Budaya Organisasi

Sumber : data diolah menggunakan SPSS versi 2018

Dari hasil analisis regresi dapat diketahui pula bahwa secara bersama-sama variabel independen memiliki pengaruh signifikan terhadap variabel dependen. Hal ini dapat dibuktikan dari $\mathrm{F}$ hitung sebesar 12,754> $F$ tabel 3,18 dan sinifikan pada 0,00 lebih kecil dari 0,05 artinya ada pengaruh yang signifikan variabel budaya organisasi dan variabel kepemimpinan secara bersamasama terhadap kinerja karyawan maka $\mathrm{Ha}$ diterima dan Ho ditolak.

\section{Pembahasan}

Setelah di ketahui hasil temuan dalam penelitian ini dan kemudian di analisis seberapa baik data tersebut untuk menjawab rumusan masalah yang sebelumnya dibahas pada bab 1 juga mempresentasikan penelitian yang diangkat, terutama kemampuan dalam menjelaskan seberapa baik pengaruh budaya orgasasi dan kepemimpinan terhadap kinerja karyawan. Selanjutnya dilakukan pembahasan terkait hasil temuantemuan dalam penelitian sebagai berikut:

1. Budaya Organisasi Terhadap Kinerja Karyawan

Berdasarkan hasil uji deskriptif, diketahui variabel budaya organisasi mayoritas responden menjawab setuju sebesar $64 \%$ berdasarkan tabel 4.17 dapat diketahui variabel budaya organisasi memiliki nilai $\mathrm{t}$ hitung 2,115>t tabel 2,00856. Berarti secara parsial budaya organisasi berpengaruh terhadap kinerja karyawan, dan diperoleh hasil signifikan 0,000 $<0,05$. Hal ini menunjukkan bahwa Ho1 ditolak dan Ha1 diterima, artinya budaya organisasi berpengaruh positif secar signifikan terhadap kinerja karyawan.

Organisasi secara parsial berpengaruh terhadap kinerja karyawan. Sehingga, jika nilai budaya organisasi naik maka kinerja karyawan akan meningkat.

2. Kepemimpinan Terhadap Kinerja Karyawan

Berdasarkan hasil uji deskriptif, diketahui variabel kepemimpinan mayoritas responden menjawab setuju sebesar $63 \%$ berdasarkan tabel 4.17 dapat diketahui variabel budaya organisasi memiliki nilai $\mathrm{t}$ hitung 2,189 $>\mathrm{t}$ tabel 2,00856. Berarti secara parsial kepemimpinan berpengaruh terhadap kinerja karyawan, dan diperoleh hasil signifikan 0,000 
$<0,05$. Hal ini menunjukkan bahwa Ho2 ditolak dan $\mathrm{Ha} 2$ diterima, artinya kepemimpinan berpengaruh positif secar signifikan terhadap kinerja karyawan. Artinya kepemimpinan secara parsial berpengaruh terhadap kinerja karyawan. Sehingga, jika nilai kepemimpinan naik maka kinerja karyawan akan meningkat.

3. Pengaruh Budaya Organisasin dan Kepemimpinan Terhadap Kinerja Karyawan

Berdasarkan hasil uji deskriptif, diketahui variabel kinerja karyawan responden menjawab setuju sebesar $71 \%$. Berdasarkan rabel 4.18 dapat diketahu bahwa $\mathrm{F}$ hitung 12,754 > F tabel 3,18 dan nilai signifikan $0,000<0,05$ maka dapat disimpulkan bahwa Ho3 ditolak dan $\mathrm{Ha} 3$ diterima, ini berarti budaya organisasi dan kepemimpinan secara simultan berpengaruh signifikan terhadap kinerja karyawan.

\section{KESIMPULAN}

Berdasarkan hasil penelitian dan pembahasan yang telah penulis uraikan pada bab sebelumnya, maka dapat disimpulkan sebagai berikut :

1. Budaya organisasi memiliki pengaruh yang posiitif dan signifikan terhadap kinerja karyawan pada perusahaan One Robotics Education. Hal ini dibuktikan dengan melihat jawaban responden dimana dari empat indikator. Hal ini dibuktikan dengan melihat jawaban responden dimana dari tiga indikator memperoleh total rata- rata responden menyatakan setuju, hal ini terlihat dari jawaban responden yang menyatakan setuju dan sangat setuju sebesar $(47,6 \%+$ $16,7 \%)=64,4 \%$. Hal ini menunjukkan bahwa pendapat responden mengenai budaya organisasi cukup baik. Berdasarkan hasil statistik dapat diketahui bahwa pengaruh budaya organisasi (X1) terhadap kinerja karyawan (Y) adalah sebesar $64,4 \%$ sedangkan sisanya $35,6 \%$ dipengaruhi oleh faktor lain. Hal ini menunjukkan bahwa budaya organisasi yang baik akan meningkatkan kinerja karyawan. Dari pengujian hipotesis diperoleh $\mathrm{t}$ hitung $>\mathrm{t}$ tabel atau $(2,115>$ 2,00856) sehingga $\mathrm{HO}$ ditolak dan $\mathrm{H} 1$ diterima artinya terdapat pengaruh yang positif dan signifikan secara parsial antara budaya organisasi terhadap kinerja karyawan. Sehingga, jika nilai budaya organisasi naik maka kinerja karyawan akan meningkat.

2. Kepemimpinan memiliki pengaruh yang posiitif dan signifikan terhadap kinerja karyawan pada perusahaan One Robotics Education. Hal ini dibuktikan dengan melihat jawaban responden dimana dari empat indikator memperoleh total ratarata responden menyatakan setuju, hal ini terlihat dari jawaban responden yang menyatakan setuju dan sangat setuju sebesar $(44,6 \%+$ $18,9 \%)=63,4 \%$. Hal ini menunjukkan bahwa pendapat responden mengenai kepemimpinan sudah baik. Berdasarkan hasil statistik dapat diketahui bahwa pengaruh kepemimpinan (X2) terhadap 
kinerja karyawan (Y) adalah sebesar $63,4 \%$ sedangkan sisanya $36,6 \%$ dipengaruhi oleh faktor lain. Hal ini menunjukkan bahwa kepemimpinan yang baik akan meningkatkan kinerja karyawan. Dari pengujian hipotesis diperoleh $\mathrm{t}$ hitung > t tabel atau $(2,189>$ 2,00856) sehingga $\mathrm{HO}$ ditolak dan $\mathrm{H} 1$ diterima artinya terdapat pengaruh yang positif dan signifikan secara parsial antara kepemimpinan terhadap kinerja karyawan. Sehingga, jika nilai kepemimpinan naik maka kinerja karyawan akan meningkat.

3. Berdasarkan hasil penelitian, menunjukkan bahwa budaya organisasi dan kepemimpinan berpengaruh positif terhadap kinerja karyawan di perusahaan One Robotics Education dengan persamaan regresi $\mathrm{Y}=6,097+$ $0,417 \mathrm{X} 1+0,423 \mathrm{X} 2$. Hasil analisis regresi menunjukkan koefisien budaya organisasi adalah sebesar 0,417 menyatakan bahwa setiap kenaikan budaya organisasi sebesar 0,417 akan meningkatkan kinerja karyawan sebesar 1 . Nilai koefisien yang positif menunjukkan bahwa budaya organisasi berpengaruh positif terhadap kinerja karyawan dan hasil analisis regresi menunjukkan keofisien kepemimpinan adalah sebesar 0,423. Semakin baik kepemimpinan yang dijalankan maka akan semakin baik pula kinerja karyawan. Demikian pula sebaliknya, kepemimpinan yang dijalankan kurang baik maka kinerja juga akan mengalami penurunan. Demikian pula dengan budaya organisasi. Kontribusi pengaruh budaya organisasi dan kepemimpinan adalah sebesar 0,338 atau 33,8\%. Hal ini menunjukkan bahwa budaya organisasi dan kepemimpinan memberikan kontribusi terhadap kinerja karyawan sebesar 33,8\% dan sisanya $66,2 \%$ dikontribusi oleh variable lain diluar penelitian, meskipun tergolong kecil namun positif. Dari pengujian hipotesis menggunakan uji statistik $F$ hitung $=12,754>3,18$ atau (Fhitung > Ftabel) sehingga H0 ditolak dan H1 diterima. Artinya terdapat pengaruh positif dan signifikan secara simultan antara budaya organisasi dan kepemimpinan terhadap kinerja karyawan.

\section{DAFTAR PUSTAKA}

Abdullah, M. 2014. Manajemen dan Evaluasi Kinerja Karyawan. Yogyakarta: Penerbit Aswaja Pressindo.

Agung, Nugroho. 2008. Strategi Jitu memilih Metode Statistik Penelitian dengan SPSS. Yogyakarta: Andi Offset.

Arikunto, Suharsimi. 2010. Prosedur Penelitian Suatu Pendekatan Praktek. Jakarta: PT. Rineka Cipta.

Bambang, Kusriyanto. 2010. Manajemen Sumber Daya Manusia. Bandung: Sulita.

Ghozali, Imam. 2011. Aplikasi Analisis Multivariate dengan Program SPSS, Edisi Kelima. Semarang: Badan Penerbit Undip.

Hamzah B. Uno. 2012. Teori Motivasi dan Pengukurannya di Bidang Pendidikan. Jakarta: PT. Bumi Aksara.

Hasibuan, Malayu S.P. 2010. Manajemen Sumber Daya 
Manusia. Jakarta: PT. Bumi Aksara

Husen, Umar. 2008. Riset Pemasaran Dan Perilaku Konsumen. Jakarta: PT. Gramedia Pustaka Utama.

Kartono, Kartini. 2011. Pemimpin dan Kepemimpinan, Edisi Kedua, Cetakan Kesembilan. Jakarta: RajaGrafindo Persada.

Ladzi, Safroni. 2012. Manajemen dan Reformasi Pelayanan Publik dalam Konteks Birokrasi Indonesia. Surabaya: Aditya Media Publishing.

Luthans, Fred. 2011. Perilaku Organisasi. Yogyakarta: Penerbit Andi.

Mangkunegoro, Anwar Prabu. 2010. Evaluasi Kinerja Sumber Daya Manusia. Bandung: Refika Aditama.

Raymond A. Noe. 2010. Human Resources Management, Gaining Copetitive Advantage Edisi ketiga. Mc Graw-Hill.

Robbins, Stephen dan Mary Coulter. 2012. Manajemen. Jakarta: PT. Indeks Kelompok Gramedia.

Robbins, Stephen P. 2012. Perilaku Organisasi, Edisi Kesepuluh, Jakarta: PT. Indeks.
Schein, Edgar H. 2010. Organizational Culture and Leadership, $3^{\text {rd }}$ Edition. San Francisco: Jossey-Bass Publishers.

Sugiyono. 2012. Metode Penelitian Kuantitatif Kualitatif dan $R$ \& $D$. Bandung: Penerbit CV. Alfabeta.

Sugiyono. 2014. Metode Penelitian Kuantitatif Kualitatif dan $R$ \& D. Bandung: Penerbit CV. Alfabeta.

Suwatno dan Donni Juni Priansa. 2011. Manajemen Sumber Daya Manusia dalam Organisasi dan Bisnis. Bandung: Alfabeta.

Syofian, Siregar. 2010. Statistika Deskriptif Untuk Penelitian. Jakarta: Rajawali Pers.

Terry, George R \& Rue, Leslie W. Rue. 2010. Dasar-Dasar Manajemen. Jakarta: Bumi Aksara.

Thoha, Miftah. 2012. Kepemimpinan Dalam Manajemen Edisi Pertama. Jakarta: PT. Raja Grafindo.

Wibowo. 2011. Manajemen Kinerja.Edisi Ketiga. Jakarta: PT Raja Grafindo Persada. 